\title{
H,K-ATPase and carbonic anhydrase response to chronic systemic rat gastric hypoxia
}

\author{
Ulfah Lutfiah, Sri W.A. Jusman, Mohamad Sadikin \\ Department Biochemistry and Molecular Biology, Faculty of Medicine, Universitas Indonesia, Jakarta, Indonesia
}

\section{ABSTRAK}

Latar belakang: Hipoksia berperan dalam terjadinya ulkus lambung yang sering dihubungkan dengan sekresi asam klorida (HCl) berlebihan. Pembentukan $\mathrm{HCl}$ melibatkan 2 jenis enzim, yaitu H,K-ATPase dan anhidrase karbonat (CA). Penelitian ini bertujuan menjelaskan mekanisme yang mendasari terjadinya ulkus lambung pada hipoksia sistemik kronik, dengan melihat respons $H, K$-ATPase dan CA9 pada tikus sebagai model hewan.

Metode: Penelitian ini merupakan penelitian eksperimental in vivo, yang bertujuan untuk menguji hubungan hipoksia terhadap ekspresi mRNA H-K-ATPase dan CA9 dan aktivitas spesifik H-K-ATPase dan CA total pada lambung tikus hipoksia sistemik kronik. Hasil uji kemudian dibandingkan dengan tikus kontrol. Data dianalisis menggunakan program SPSS. Jika distribusi data normal dan homogen, uji ANOVA dan LSD post-hoc digunakan, tetapi jika distribusi data tidak normal dan homogen, dilakukan transformasi data, kemudian digunakan uji nonparametrik yaitu Kruskal-Wallis dan Mann Whitney. Sebanyak 25 tikus Sprague-Dawley dibagi menjadi 5 kelompok, yaitu kelompok kontrol tanpa hipoksia dan kelompok hipoksia 1, 3, 5, dan 7 hari yang ditempatkan dalam kotak hipoksia $\left(\mathrm{O}_{2}, 10 \%\right.$ dan $\mathrm{N}_{2}$ 90\%). Setelah perlakuan, tikus dieutanasia, lambung tikus diisolasi, dihomogenisasi, kemudian dilakukan pengukuran ekspresi mRNA H,K-ATPase dan CA9 menggunakan real time RT-PCR, aktivitas spesifik H,K-ATPase menggunakan larutan standar fosfat, dan aktivitas spesifik CA9 total menggunakan larutan standar p-nitrofenol (pNP).

Hasil: Ekspresi mRNA H,K-ATPase lebih tinggi pada hari pertama $(2,159)$ dan turun drastis mulai hari ketiga sampai ketujuh (0,289; 0,108; 0,062). Aktivitas spesifik H,K-ATPase sedikit lebih tinggi pada hari pertama $(0,765)$, turun pada hari ketiga $(0,685)$ dan kelima $(0,655)$, naik kembali pada hari ketujuh $(0,884)$. Ekspresi mRNA CA9 menurun mulai hari pertama sampai hari ketujuh $(0,84 ; 0,766 ; 0,736 ; 0,343)$. Aktivitas spesifik CA total lebih rendah pada hari pertama $(0,083)$, kemudian lebih tinggi kembali pada hari ketiga sampai hari ketujuh $(0,111 ; 0,136 ; 0,144)$.

Kesimpulan: Pada keadaan hipoksia, ekspresi mRNA HKATPase dan CA9 menurun, tetapi aktivitas spesifik HK-ATPase dan CA total meningkat.

\section{ABSTRACT}

Background: Hypoxia may induce gastric ulcer associated with excessive hidrogen chloride $(\mathrm{HCl})$ secretion. Synthesis of $\mathrm{HCl}$ involves 2 enzymes, H,K-ATPase and carbonic anhydrase (CA). This study aimed to clarify the underlying cause of gastric ulcer in chronic hypoxic condition, by investigating the $\mathrm{H}, \mathrm{K}-\mathrm{ATPase}$ and CA9 response in rats.

Methods: This study was an in vivo experiment, to know the relationship between hypoxia to expression of H,K-ATPase and CA9 mRNA, and H,K-ATPase and total CA specific activity of chronic systemic rat gastric hypoxia. The result was compared to control. Data was analyzed by SPSS. If the data distribution was normal and homogeneous, ANOVA and LSD post-hoc test were used. However, if the distribution was not normal and not homogeneous, and still as such after transformation, data was treated in non-parametric using Kruskal-Wallis and Mann Whitney test. Twenty five male Sprague-Dawley rats were divided into 5 groups: rats undergoing hypoxia for $1,3,5$, and 7 days placed in hypoxia chamber $\left(10 \% \mathrm{O}_{2}, 90 \% \mathrm{~N}_{2}\right)$, and one control group. Following this treatment, stomach of the rats was extracted and homogenized. Expression of H,K-ATPase and CA9 mRNA was measured using real time RT-PCR. Specific activity of H,K-ATPase was measured using phosphate standard solution, and specific activity of total CA was measured using p-nitrophenol solution.

Results: The expression of H,K-ATPase mRNA was higher in the first day (2.159), and drastically lowered from the third to seventh day $(0.289 ; 0.108 ; 0.062)$. Specific activities of $\mathrm{H}, \mathrm{K}-\mathrm{ATPa}$ e was slightly higher in the first day $(0.765)$, then was lowered in the third (0.685) and fifth day $(0.655)$, and was higher in the seventh day (0.884). The expression of CA9 mRNA was lowered progressively from the first to seventh day $(0.84 ; 0.766 ; 0.736 ; 0.343)$. Specific activities of total CA was low in the first day (0.083), and was higher from the third to seventh day $(0.111 ; 0.136 ; 0.144)$.

Conclusion: In hypoxia condition, expression of H,K-ATPase and CA9 mRNA were decreased, but the specific activity of $\mathrm{H}$,K-ATPase and total CA were increased.

Keywords: carbonic anhydrase, gastric ulcer, H,K-ATPase, hypoxia

pISSN: 0853-1773 • eISSN: 2252-8083 • http://dx.doi.org/10.13181/mji.v24i3.1066 • Med J Indones. 2015;24:133-8

- Received 09 Oct 2014 • Accepted 21 Sep 2015

Correspondence author: Ulfah Lutfiah, ulfah83lutfiah@yahoo.com

Copyright @ 2015 Authors. This is an open access article distributed under the terms of the Creative Commons Attribution-NonCommercialShareAlike 4.0 International License (http://creativecommons.org/licenses/by-nc-sa/4.0/), which permits unrestricted non-commercial use, distribution, and reproduction in any medium, provided the original author and source are properly cited. 
Oxygen is an important element in living organisms, especially for aerobic organisms. It functions as a final electron in respiratory chain in mitochondria and releases energy by forming water as by product. In physiological condition, the released energy is captured in the form of high energy covalent bounds, the adenosine triphosphate (ATP). ${ }^{1-4}$ Hence, the availability of ATP is very important for the survival of organism. Under normoxia condition, aerobic cells obtains ATP from respiratory chains in the mitochondria. However, organisms or cells may undergo hypoxic conditions. In this case, ATP is synthesized using the anaerobic way, which is less efficient and associated with increased acid production. ${ }^{1}$ Therefore, in an attempt to obtain an equivalent amount of ATP through aerobic metabolism, the hypoxic process is associated with an increase of lactic acid, which is then ionized immediately into hidrogen $\left(\mathrm{H}^{+}\right)$and lactate. ${ }^{4}$

Recently, it was reported that rats exposed to chronic hypoxia developed gastric ulcer, $^{5}$ a disease usually associated with increasing hidrogen chloride $(\mathrm{HCl})$ secretion. hidrogen, potassium-ATPase (H,K-ATPase) is a membrane bound enzyme also called proton pump and has pivotal role in the secretion of $\mathrm{HCl}$ from parietal cells. ${ }^{6,7} \mathrm{H}^{+}$is secreted by this enzyme into the gastric lumen in an exchange with kalium $\left(\mathrm{K}^{+}\right)$ on the expense of one ATP. On the other hand, $\mathrm{H}^{+}$ itself is derived from the ionization of carbonic acid $\left(\mathrm{H}_{2} \mathrm{CO}_{3}\right)$ into bicarbonate ion $\left(\mathrm{HCO}_{3}^{-}\right)$and $\mathrm{H}^{+}$, a reaction catalyzed by carbonic anhydrase (CA). ${ }^{8}$

The aim of this study was to investigate one of the underlying causes of gastric ulcer in chronic normobaric hypoxic condition, by exploring the $\mathrm{H}, \mathrm{K}-\mathrm{ATP} a \mathrm{se}$ and CA response in rats.

\section{METHODS}

This study was in vivo experiment, to know the relationship between hypoxia to expression of H,K-ATPase and CA9 messenger-ribonucleic acid (mRNA), and H,K-ATPase and total CA specific activity of chronic systemic rat gastric hypoxia. The result was compared to control. Sprague-Dawley male rats, weighing 150-200 grams were used in this study. The animals were obtained from The Institute of Health Research and Development, Ministry of Health, Republic of Indonesia. Protocol of this experiment was approved by Research Ethics Committee of the Faculty of Medicine, Universitas Indonesia, No. 114/H2.F1/ETIK/2013. The experiment was conducted from February 2013 until May 2014.

\section{Hypoxia treatment}

Animals were divided into five groups of five rats each. The groups consisted of rats undergoing one, three, five, and seven days of hypoxia condition versus control. Rats of the control group were placed in an environment with air condition while rats of the other groups were placed in a closed hypoxic chamber which had no access to environment air and connected only to a tube delivering $10 \% \mathrm{O}_{2}$ and $90 \% \mathrm{~N}_{2}$ in $1 \mathrm{~atm}$ pressure. Prior to the experiment, animals were placed in the animal house for two weeks, and in the hypoxic chamber for six hours. All animals had free access to a standard food and water. After each determined period, rats were sacrificed, stomachs were extracted and kept in deep freezer at $-80^{\circ} \mathrm{C}$.

\section{mRNA expression assay}

mRNA expression assay was performed for $\mathrm{H}, \mathrm{K}-$ ATPase, CA9, using 18sRNA as housekeeping gene based on the copy number of complementarydeoxyribonucleic acid (cDNA) produced from each mRNA and synthesized by real time reverse transcription polymerase chain reaction (RT-PCR) technique. For H,K-ATPase, accession number in National Center for Biotechnology Information (NCBI) is NM_012509.1, primer sequences are ATGGGGAAGGCAGAGAATTATGA (forward) and TGACAACTGGTGGTCGTTCA (reverse). For CA9, accession number in NCBI is NM_001107956.1, primer sequences are GCTAAGCAGCTCCATACGCT (forward) and GCCAAACACCAAGGCTAGGA (reverse). For 18sRNA accession number in NCBI is NR_046237.1, primer sequences are CGCGGTTCTATTTTGTTGGT (forward) and AGTCGGCATCGTTTATGGTC (reverse). ${ }^{9}$ mRNAs were isolated from gastric mucosal homogenates, following preparation of $25 \mathrm{mg}$ gastric mucosal and $500 \mu \mathrm{L}$ tripure isolation reagent (Roche). Isolation of mRNA was performed according to the procedure described in the kit instruction manual. Relative expression of mRNAs was measured using real time RT-PCR Mini Opticon (BIO RAD) with software Bio-Rad CFX Manager. Each reaction mixture contained $1 \mu \mathrm{L}$ RNA template (equivalent to $100 \mathrm{ng}$ RNA), $0.2 \mu \mathrm{L}$ 
forward primer, $0.2 \mu \mathrm{L}$ reverse primer, $0.2 \mu \mathrm{L}$ KAPA-RT Mix, $5 \mu \mathrm{L}$ KAPA SYBR FAST master mix, and 13.4 $\mu \mathrm{L}$ nuclease free water. Reaction for cDNA amplification performed using KAPA SYBR FAST one-step qRT-PCR, according to the procedure described in the kit instruction manual. Relative gene expression was counted according to Livak's method. ${ }^{10}$

\section{H,K-ATPase enzyme assay}

ATP hydrolytic activity of rat stomach was quantified as orthophosphate released from substrate ATP using a colorimetric malachite green procedure ${ }^{11}$ Specific activity of H,K-ATPase was calculated as the difference of ATPase activity in the presence and absence of the specific gastric H,K-ATPase inhibitor SCH28080, and were expressed as $\mu \mathrm{mol}$ Pi released/mg protein/ minute.

The mucosal tissue was dissected from rat stomach, homogenized, followed by three freezed thawed cycles at $-80^{\circ} \mathrm{C}$ and room temperature. The cell membrane fraction was separated by differential centrifugation. ${ }^{12}$ Firstly, the mixture was centrifuged at $600 \mathrm{~g}$ for 10 minutes. The supernatant was taken, placed in the other centrifuge tube and underwent separation at $10,000 \mathrm{~g}$ for 10 minutes. The second supernatant was centrifuged at 30,000 g for one hour. After this last centrifugation, the supernatant was discarded and the pellet was dissolved in Tris $\mathrm{HCl}$ buffer $60 \mathrm{mM} \mathrm{pH} \mathrm{7.4.} \mathrm{The} \mathrm{H,K-ATPase} \mathrm{activity} \mathrm{was}$ assayed from this last fraction using the Smolka technique. Briefly, ATPase assays were carried out in 96-well microplates. Each well contained of $20 \mu \mathrm{L} 1 \mathrm{mM}$ ATP, $5 \mu \mathrm{L}$ enzyme (or $8 \mu \mathrm{L}$, added wih $3 \mu \mathrm{L} 50 \mu \mathrm{M} \mathrm{SCH} 28080$ for inhibition assay), and completed with bi-destillation water to 50 $\mu \mathrm{L}$. The mixture was incubated for 30 minutes at $37^{\circ} \mathrm{C}$. Enzymatic activity was stopped by addition of malachite green reagent containing $5 \mu \mathrm{L}$ acid solution (incubated 10 minutes at room temperature) and $15 \mu \mathrm{L}$ for blue solution (incubated 20 minutes at room temperature). For blank, $50 \mu \mathrm{L}$ bi-destillation water was mixed with $5 \mu \mathrm{L}$ for acid solution and $15 \mu \mathrm{L}$ blue solution. ${ }^{13}$

The activity of H,K-ATPase is expressed as amount of phosphate released and bound with malachite green to produce a compound with maximum absorbance at $620 \mathrm{~nm}$. A standard curve was derived from a series of standard phosphate solution ranging from 0 to $1.25 \mathrm{nmol} / 50 \mu \mathrm{L}$.

\section{Total CA enzyme assay}

The total CA specific activity was measured according to technique Verrpoorte, modified by Ozdemir. ${ }^{12}$ In principle, p-nitrophenil acetat (pNPA) was hydrolyzed by CA to form p-nitrophenol (pNP). The yellow color intensity of pNP is proportional to the amount of the substrate pNPA.

CA activity was estimated by mixing $750 \mu \mathrm{L} 0.03$ nmol pNPA, $50 \mu \mathrm{L}$ sample and $700 \mu \mathrm{L}$ tris sulfate buffer $0.1 \mathrm{M}$ (pH 7.4). Absorbance of the sample at $348 \mathrm{~nm}$ was measured in a spectrophotometer after three minutes of incubation at room temperature. A standard curve was derived from a series of pNP solution ranging from zero to $100 \mathrm{nmol} / \mathrm{mL}$.

\section{Data analysis}

Data were analyzed by SPSS program version 16. If the data distribution was normal and homogeneous, ANOVA and LSD post-hoc test were used. However, if the distribution was not normal and not homogeneous, and still as such after transformation, data was treated in nonparametric way using Kruskal-Wallis and Mann Whitney test. A p-value of $<0.05$ was taken as the limit of statistical significance.

\section{RESULTS}

\section{H,K-ATPase assay}

The expression of H,K-ATPase mRNA is significantly higher (Kruskal-Wallis, $p=0.003$ ) at the first day hypoxia, and decreased drastically from the third to seventh day. (Figure 1).

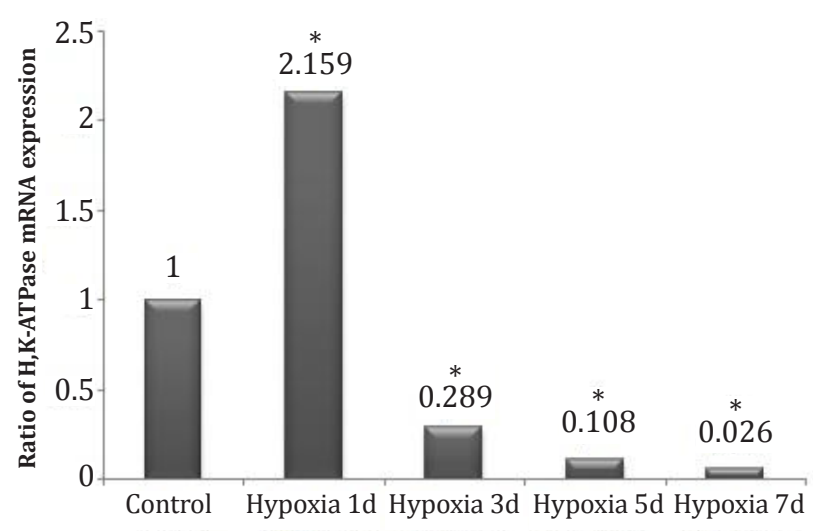

Figure 1. Ratio of H,K-ATPase mRNA expression. ${ }^{*} \mathrm{p}<0.05$ vs control 
Specific activity of enzyme was higher slightly in the first day, than was lowered slightly in the third and fifth day, and was higher again in the seventh day. The highest activity was in the seventh day. Over all, the change was not significant $(n=25, p=0.126)$. (Figure 2 ).

\section{Carbonic anhydrase assay}

The expression of CA9 mRNA decreased from the first to seventh day of hypoxia, although the changes were not significant (Kruskal-Wallis, $n$ $=25, p=0.060$ ). The treatment groups showed a lower number of mRNA than the control group, whereby the lowest was seventh day (Figure 3).

Specific activity of total CA was significantly decreased in the first day (ANOVA, $p=0.003$ ), followed by a markedly higher activity at day three, five, and seven (Figure 4).

\section{DISCUSSION}

Stomach is the first part of digestive tract and only secretes one enzyme, the pepsin, which needs $\mathrm{HCl}$ as an activator. The stomach does not absorb the digested food, however, it is very important for the protection of distal digestive tract by $\mathrm{HCl}$ secretion. Moreover, the gastric mucosa secretes intrinsic factor, an important glicoprotein which binds vitamin B12. Vitamin B12 itself is absorbed in the ileum. There is a close relationship between intrinsic factor and $\mathrm{HCl}$ production. Glicoprotein (intrinsic factor) bind with vitamin B12 form intrinsic factor vitamin B12 complex. The complex binds ileum receptor, and then absorbs the vitamin B12. The more $\mathrm{HCl}$ amount can influence to vitamin B12, the more vitamin B12 can be absorbed. In the condition of achlorhydria, characterized by the absence of $\mathrm{HCl}$ in the stomach, the absorption of vitamin B12 is impaired, resulting in vitamin B12 deficiencies. Consequently, the patients will suffer from anemia and peripheral neural symptoms. ${ }^{14}$

On the other hand, peptic ulcer is often associated with hyperacidity and $\mathrm{HCl}$ being considered as the main cause. Syam, et al ${ }^{5}$ reported that gastric ulcer was developed in rats suffering from systemic hypoxia. The authors also found that expression of hypoxia inducible factor -1 (HIF-1) was increased in rat stomach. ${ }^{5}$ It is well known that CA expression, especially CA9 is under control of HIF-1, suggesting

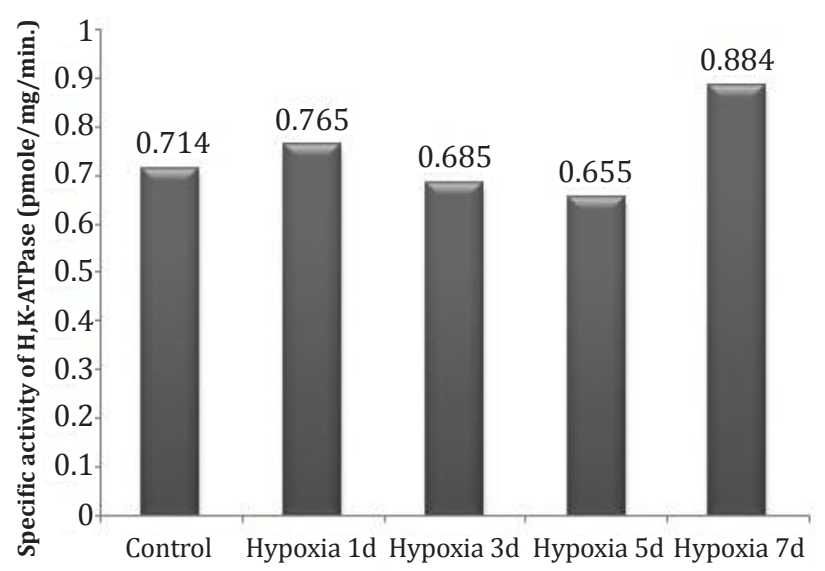

Figure 2. Specific activity of H,K-ATPase

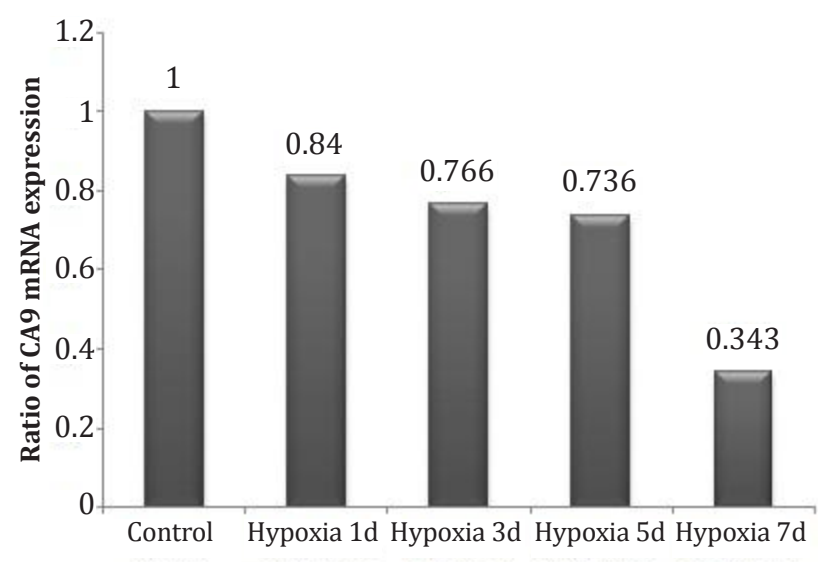

Figure 3. Ratio of CA 9 mRNA expression

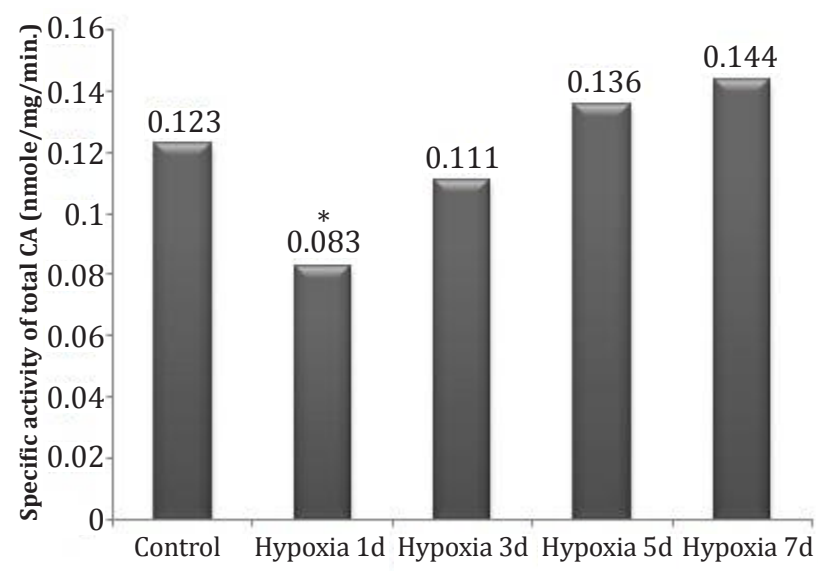

Figure 4. Specific activity of total CA. ${ }^{*)} \mathrm{p}<0.05$ vs control

that CA activity increases under hypoxic condition. The present study tries to explain the mechanism how hypoxia related with $\mathrm{HCl}$ secretion and to gastric ulcer formation as reported by Syam, et $\mathrm{al}^{5}$ by investigating the CA and H,K-ATPase enzymes. 
$\mathrm{HCl}$ secretion involves two steps. Firstly, the activity of $\mathrm{CA}$ which catalyzes conversion of $\mathrm{H}_{2} \mathrm{CO}_{3}$ into $\mathrm{HCO}_{3}$ and $\mathrm{H}^{+}$as the source of $\mathrm{H}^{+}$. The second step is the secretion of $\mathrm{H}^{+}$in exchange with $\mathrm{K}^{+}$. As this process is against concentration gradient, it needs an energy source in the form of ATP. ${ }^{14}$ The process is catalyzed by H,K-ATPase also known as proton pump.

Our study indicated that the expression of proton pump at the mRNA level was significantly higher in the first day of hypoxia, followed by a decrease from day three to seven of hypoxia. Thus, it can be concluded that the expression of H,K-ATPase appears to be induced by hypoxia. However, concerning specific enzyme activity, there is no significant difference between control and hypoxic states at different days. This suggests that high level of mRNA at day one of hypoxia was not translated into protein. It is not easy to explain the relation between mRNA level with the constant activity of enzyme, because the correlation is very weak.

The proton pump is a membrane integral protein of the parietal cell of the stomach. We did not find any information indicating that the proton pump is a constitutive protein. However as this protein is supposed to permanently secrete $\mathrm{HCl}$, the synthesized enzyme may be stored in the parietal cell membrane. As a consequence, in case of stimuli for secretion, the protein may not need to be synthesized de novo. The proton need is fulfilled by the activities of CA. We demonstrated that the activity of total CA increased during observation. However, the synthesis of CA9 mRNA decreased from day one until seven when compared to control. Gastric tissue expresses three isoforms of CA i.e: CA2, CA9, and CA12. Usually CA9 expression increases in hypoxic condition. ${ }^{15}$ This phenomenon is usually used as an indicator of hypoxic state in a cell or a tissue. But in stomach, it is the CA9 which is dominant under normal condition. Some authors reported that in gastric cancer, the CA9 expression decreases in contrary to other cancer. ${ }^{16-18}$ Malignant tissue is usually found in hypoxic condition. ${ }^{16}$ Interestingly, in our experiments in hypoxic condition, the expression of CA9 also decreased. In order to explain the increase of activity during this experiment, we have to see to other CA isoform. One study reported ${ }^{17}$ that in the gastric cancer, CA12 increases along with CA9. Thus, it can be suggested that high activities of total CA was due to high activities of CA12.
Hidrogen chloride is the main cause of peptic ulcer. However, even in the absence of $\mathrm{HCl}$, peptic ulcer can be developed. Pepsin, the protease secreted by chief cells and the mucin is secreted by the goblet cells, plays a role in causing peptic ulcer. Pepsin is very strong protease, and can damage the mucosal lining. ${ }^{19}$ Mucosal fluid (mucin) is very important to protect the mucus layer. ${ }^{19}$ The composition of mucin is very complex. It contains various mucoproteins and ions, which can neutralize and trap $\mathrm{HCl}$ or trap the enzyme. This is on of mechanisms how mucosal fluid protect the mucosal layer. Composition of any mucosal fluid from various sources can vary according to condition. It is possible that the composition of gastric mucosal fluid in hypoxia condition is changed when compared to normal condition.

Overall, we have conclude that the proton pump mRNA responses also under hypoxic condition, however, it may not be translated into the protein. On the other hand, CA9 expression decreases in the hypoxia condition, but the total CA activity increases.

\section{Acknowledgment}

This study was part of Research Project entitled "Regulation of glutaminase, carbonic anhydrase, H,K-ATPase and carbamoyl phosphate synthetase expression by HIF-1 in hypoxia condition", funded by DRPM-UI research grant No. DRPM/RII/238/ RU-UI/2.

\section{Conflicts of interest}

The authors affirm no conflict of interest in this study.

\section{REFERENCES}

1. Gilany K, Vafakhah M. Hypoxia: a review. J Paramed Sci. 2010;1(2):43-60.

2. Taylor CT. Mitochondria and cellular oxygen sensing in the HIF pathway. Biochem J. 2008;409(1):19-26.

3. Semenza GL. Oxygen-dependent regulation of mitochondrial respiration by hypoxia-inducible factor 1. Biochem J. 2007;405(1):1-9.

4. Alberti KG. The biochemical consequences of hypoxia. J Clin Pathol Suppl (R Coll Pathol). 1977;11:14-20.

5. Syam AF, Simadibrata M, Wanandi SI, Hernowo BS, Sadikin M, Rani AA. Gastric ulcers induced by systemic hypoxia. Acta Med Indones. 2011;43(4):243-8.

6. Shin JM, Munson K, Vagin O, Sachs G. The gastric HKATPase: structure, function, and inhibition. Pflugers Arch. 2009;457(3):609-22. 
7. Munson K, Lambrecht N, Shin JM, Sachs G. Analysis of the membrane domain of the gastric $\mathrm{H}^{+} / \mathrm{K}^{+}$-ATPase. J Exp Biol. 2000;203:161-70.

8. Harper HA. Review of physiological chemistry. 15th ed. Los Altos: Lange Medical publication; 1975.

9. ncbi.nlm.nih.gov [Internet]. Primer BLAST tools [cited 2013 Mar 8]. Available from: http://www.ncbi.nlm.nih. gov/tools/primer-blast/.

10. Livak KJ, Schmittgen TD. Analysis of relative gene expression data using real-time quantitative PCR and tha 2(-Delta Delta C(T)) method. Methods. 2001:25(4);402-8.

11. Smolka AJ, Goldenring JR, Gupta S, Hammond CE. Inhibition of gastric $\mathrm{H}, \mathrm{K}-\mathrm{ATPa}$ e activity and gastric epithelial cell IL-8 secretion by the pyrrolizine derivative ML 3000. BMC Gastroenterol. 2004;4(4):1-11.

12. Özdemir H, Küfrevioğlu O, Çetinkaya R. Effects of glycation on erythrocyte anhydrase-I and II patients with diabetes mellitus. Turk J Med Sci. 2000;30:135-41.

13. Wood EJ. An introduction to centrifugation by T C Ford and J M Graham. Biochem Edu. 1991;19(3):157.

14. Healton EB, Savage DG, Brust JC, Garrett TJ, Lindenbaum
J. Neurologic aspects of cobalamin deficiency. Medicine (Baltimore). 1991;70(4):229-45.

15. Mayer A, Höckel M, Vaupel P. Carbonic anhydrase IX expression and tumor oxygenation status do not correlate at the microregional level in locally advanced cancers of the uterine cervic. Clin Cancer Res. 2005,11(20):7220-5.

16. Pastorekova S, Zavada J. Carbonic anhydrase IX (CA IX) as a potential target for cancer therapy. Cancer Ther. 2004;2:245-62.

17. Leppilampi M, Saarnio J, Karttunen TJ, Kivelä J, Patoreková S, Pastorek J, et al. Carbonic anhydrase isozymes IX and XII in gastric tumors. World J Gastroenterol. 2003;9(7):1398-403.

18. Hilvo M, Baranauskiene L, Salzano AM, Scaloni A, Matulis D, Innocenti A, et al. Biochemical characterization of CA IX, one of the most active carbonic anhydrase isozymes. J Biol Chem. 2008;283(41):27799-809.

19. Allen A, Garner A. Mucus and bicarbonate secretion in the stomach and their possible role in mucosal protection. Gut. 1980;21(3):249-62. 